\title{
AMCoR
}

Asahikawa Medical College Repository http://amcor. asahikawa-med. ac. jp/

Free Radical Biology and Medicine (2007) 43(11):1552-1559.

Lipid peroxidation and 4-hydroxy-2-nonenal formation by copper ion bound to amyloid $-\beta$ peptide.

Hayashi T, Shishido N, Nakayama K, Nunomura A, Smith MA, Perry G, Nakamura M. 


\section{Lipid peroxidation and 4-hydroxy-2-nonenal formation by copper ion bound to amyloid-beta peptide}

Takaaki Hayashi ${ }^{\dagger}$, Naomi Shishido ${ }^{\ddagger}$ Kenji Nakayama ${ }^{\dagger}$, Akihiko Nunomura ${ }^{\S}$, Mark A. Smith", George Perry ${ }^{\|}$and Masao Nakamura**

${ }^{\dagger}$ Hokkaido Institute of Public Health, Kita 19, Nishi 12, Kita-ku, Sapporo 060-0819, Japan;

${ }^{\ddagger}$ Department of Chemistry, and ${ }^{\S}$ Department of Psychiatry and Neurology, Asahikawa Medical College, Asahikawa 078-8510, Japan; "Department of Pathology Case Western Reserve University, Cleveland, Ohio 44106, USA; and "College of Sciences, The University of Texas at San Antonio, One UTSA Circle, San Antonio, Texas 78249, USA

*To whom correspondence should be addressed to Masao Nakamura, Department of Chemistry, Asahikawa Medical College, Asahikawa 078-8510, Japan,

Tel : +81-166-68-2724, Fax : +81-166-68-2782, E-mail: nmasao@asahikawa-med.ac.jp

Running title: Lipid peroxidation and $\mathrm{HNE}$ formation by $\mathrm{A} \beta-\mathrm{Cu}^{2+}$ 


\section{Lipid peroxidation and 4-hydroxy-2-nonenal formation by copper ion bound to amyloid-beta peptide}

Abstract - The lipid peroxidation product 4-hydroxy-2-nonenal (HNE) is proposed to be a toxic factor in the pathogenesis of Alzheimer's disease. The primary products of lipid peroxidation are phospholipid hydroperoxides and degraded reactive aldehydes, such as HNE, as secondary peroxidation products. In this study, we investigated the role of amyloid- $\beta$ peptide $(A \beta)$ in the formation of phospholipid hydroperoxides and HNE by copper ion bound to A $\beta$. The $\mathrm{A} \beta_{1-42}-\mathrm{Cu}^{2+}$ (1:1 molar ratio) complex showed an activity to form phospholipid hydroperoxides from phospholipid, 1-palmitoyl-2-linoleoyl phosphatidylcholine (PLPC), through $\mathrm{Cu}^{2+}$ reduction in the presence of ascorbic acid. The phospholipid hydroperoxides were considered to be racemic mixture of 9-hydroperoxide and 13-hydroperoxide of linoleoyl residue. When $\mathrm{Cu}^{2+}$ was bound to two molar equivalents of $A \beta_{1-42}\left(2 \mathrm{~A} \beta_{1-42}-\mathrm{Cu}^{2+}\right)$, lipid peroxidation was inhibited. HNE was generated from one of the phospholipid hydroperoxides, 1-palmitoyl-2-(13-hydroperoxy-cis-9, trans-11-octadecadienoyl) phosphatidylcholine (PLPC-OOH), by free $\mathrm{Cu}^{2+}$ in the presence of ascorbic acid through $\mathrm{Cu}^{2+}$ reduction and degradation of PLPC-OOH. HNE generation was markedly inhibited by equimolar concentrations of $A \beta_{1-40}(92 \%)$ and $A \beta_{1-42}(92 \%)$. However, $A \beta_{1-42}$ binding two or three molar equivalents of $\mathrm{Cu}^{2+}\left(\mathrm{A} \beta_{1-42}-2 \mathrm{Cu}^{2+}, A \beta_{1-42}-3 \mathrm{Cu}^{2+}\right)$ acted as a pro-oxidant to form HNE from PLPC-OOH. These findings suggest that, at moderate concentrations of copper, $A \beta$ acts primarily as an antioxidant to prevent $\mathrm{Cu}^{2+}$-catalyzed oxidation of biomolecules, but that, in the presence of excess copper, pro-oxidant complexes of $\mathrm{A} \beta$ with $\mathrm{Cu}^{2+}$ are formed.

Keywords - amyloid- $\beta$ peptide, copper, lipid peroxidation, 4-hydroxy-2-nonenal, phospholipid hydroperoxide, Alzheimer's disease, antioxidant

\section{INTRODUCTION}

Alzheimer's disease is characterized by deposition of aggregated amyloid- $\beta$ peptide $(A \beta)$ and oxidative stress marked by protein and RNA oxidation and lipid peroxidation (1-5). Lipid peroxidation in vivo involves mainly unsaturated fatty acyl residues esterified in phospholipids. The primary peroxidation products are phospholipid hydroperoxides having a hydroperoxy unsaturated fatty acyl residue (Fig. 1) (6,7). The phospholipid hydroperoxides are degraded to reactive aldehydes, such as 4-hydroxy-2-nonenal (HNE) (Fig.1), malondialdehyde and alkenals, as secondary peroxidation products (8-10), and the HNE has been demonstrated to cause neuronal death (11-14). The HNE-protein adducts are detected in the brain of patients with Alzheimer's disease (15-17). Therefore, HNE is considered to play a crucial role in oxidative 
injury of biomolecules related to Alzheimer's disease but the role of A $\beta$ in the formation of HNE is unknown.

The formation of HNE has been demonstrated by the reaction of one of the phospholipid hydroperoxides, 1-palmitoyl-2-(13-hydroperoxy-cis-9, trans-11-octadecadienoyl) phosphatidylcholine (PLPC-OOH), with hemoprotein (18). Lipid hydroperoxides are generally known to be degraded by transition metal ions and is known that $A \beta$ shows a strong affinity for transition metal ions, especially $\mathrm{Cu}^{2+}$ such that $\mathrm{A} \beta$ is assumed to bind with $\mathrm{Cu}^{2+}$ physiologically (19-23). The $\mathrm{A} \beta-\mathrm{Cu}^{2+}$ complex is reported to act as a pro-oxidant (24-27), an especially deleterious aspect since $A \beta$ is rich in hydrophobic amino acids in the carboxyl-terminal region and is present in phospholipids with lipoproteins of both cerebrospinal fluid and plasma $(28,29)$. Indeed, the lipoprotein of human cerebrospinal fluid is reported to be easily oxidized in vitro to generate phospholipid hydroperoxides $(30,31)$ - an aspect that might account for the reduced concentrations of fatty acids in Alzheimer's disease. Therefore, we hypothesized that phospholipid hydroperoxides and $\mathrm{HNE}$ could be formed from phospholipids by the $\mathrm{A} \beta-\mathrm{Cu}^{2+}$ complex. In support of this concept, in this study, we found that the $\mathrm{A} \beta-\mathrm{Cu}^{2+}$ complex have an activity to generate phospholipid hydroperoxides from phospholipids. Moreover, we show that when $\mathrm{Cu}^{2+}$ concentration is higher than $\mathrm{A} \beta$, in the presence of ascorbic acid (Fig.1), HNE could be detected as a reaction product from the phospholipid hydroperoxides with the $\mathrm{A} \beta-\mathrm{Cu}^{2+}$ complex.

\section{MATERIALS AND METHODS}

\section{Materials}

Human $A \beta_{1-40}$ and $A \beta_{1-42}$ were purchased from Peptide Institute Inc. (Osaka, Japan); $A \beta_{1-28}$, $\mathrm{A} \beta_{35-42}$, L-carnosine, trientine (triethylenetetramine), penicillamine, clioquinol (5-chloro-7-iodo-8-hydroxyquinoline), deferoxamine and glycyl-L-histidyl-L-lysine (GHL) from Sigma-Aldrich (St. Louis MO, USA); EDTA, oxine (8-hydroxyquinoline), histidine, histamine, spermine, spermidine and putrescine from Wako Pure Chemical Co. (Osaka, Japan); 4-hydroxy-2-nonenal (HNE) from Cayman chemical Co.; and 1-palmitoyl-2-linoleoyl phosphatidylcholine (PLPC) from Avanti Polar Lipids, Inc. (Alabaster, USA). 1-palmitoyl-2-(13-hydroperoxy-cis-9, trans-11-octadecadienoyl) phosphatidylcholine (PLPC-OOH) was prepared from PLPC as described previously (18, 32, 33). Other chemicals were of the highest quality commercially available.

Determination of phospholipid hydroperoxides and HNE.

The determination of phospholipid hydroperoxide and HNE with high performance liquid chromatography (HPLC) was performed on a Hitachi model L-6000 liquid chromatograph. The HPLC conditions for the determination of HNE were described previously (18). An ODS 
column $(5 \mu \mathrm{m}, 4.6 \times 250 \mathrm{~mm}$, TSK ODS-80Ts, Tosoh Co., Tokyo, Japan) was used. The mobile phase was acetonitrile/50 $\mathrm{mM}$ phosphate buffer $(\mathrm{pH} 2.7)(3: 7 ; \mathrm{v} / \mathrm{v})$, and the flow rate was 1.4 $\mathrm{ml} / \mathrm{min}$. The UV peaks were monitored at $222 \mathrm{~nm}$, the absorption maximum of HNE. The chemiluminescence detection-high performance liquid chromatography (CL-HPLC) conditions for the determination of PLPC-OOH were described previously (18). An ODS column ( $5 \mu \mathrm{m}$, $4.6 \times 250 \mathrm{~mm}$, TSK ODS-80Ts, Tosoh Co., Tokyo, Japan) was used. The mobile phase was acetonitrile /methanol/water $(75: 23: 2, \mathrm{v} / \mathrm{v} / \mathrm{v})$ containing $10 \mathrm{mM}$ choline chloride and the flow rate was $1.5 \mathrm{ml} / \mathrm{min}$. The eluent was mixed at post-column with chemiluminescence reagent which consisted of $0.15 \mu \mathrm{M}$ cytochrome c, $10.0 \mu \mathrm{M}$ luminol, $1.0 \mathrm{mM}$ EDTA and $20 \mathrm{mM}$ $\mathrm{H}_{3} \mathrm{BO}_{3}-\mathrm{Na}_{2} \mathrm{CO}_{3}$ buffer ( $\mathrm{pH}$ 10), with a $2.5-\mathrm{ml} / \mathrm{min}$ flow rate. Phospholipid hydroperoxides were detected with the chemiluminescence detector (Shimadzu CLD-10A). PLPC-OOH was used as external standard to determine phospholipid hydroperoxides.

Phospholipid hydroperoxide formation from PLPC by $A \beta_{1-42}-C u^{2+}$ complex.

The reaction mixture containing PLPC $(1 \mathrm{mM})$ and ascorbic acid $(2 \mathrm{mM})$ was incubated with $\mathrm{Cu}^{2+}(10 \mu \mathrm{M})$ or $\mathrm{A} \beta_{1-42}(3.3 \sim 20 \mu \mathrm{M})-\mathrm{Cu}^{2+}(10 \mu \mathrm{M})$ complex $\left(\mathrm{A} \beta_{1-42} / \mathrm{Cu}^{2+}=2: 1,1: 1,1: 2\right.$ and 1:3) in $5 \mathrm{mM}$ HEPES buffer ( $\mathrm{pH} 7.4)$ at room temperature. An aliquot of the reaction mixture was directly injected into a CL-HPLC to determine phospholipid hydroperoxides.

Effects of chelator on phospholipid hydroperoxide formation from PLPC by $\mathrm{A \beta}_{1-42} \mathrm{Cu}^{2+}$ complex.

The reaction mixture containing PLPC $(1 \mathrm{mM})$, ascorbic acid $(2 \mathrm{mM})$ and $\mathrm{A} \beta_{1-42}(10 \mu \mathrm{M})$ $-\mathrm{Cu}^{2+}(10 \mu \mathrm{M})(1: 1$ molar ratio) complex was incubated with $10 \mu \mathrm{M}$ chelator for 60 minutes in 5 $\mathrm{mM}$ HEPES buffer ( $\mathrm{pH}$ 7.4) at room temperature. An aliquot of the reaction mixture was directly injected into the CL-HPLC to determine phospholipid hydroperoxides.

HNE formation from PLPC-OOH by $\mathrm{Cu}^{2+}$.

The reaction mixture containing PLPC-OOH $(500 \mu \mathrm{M}), \mathrm{Cu}^{2+}(1 \sim 3 \mu \mathrm{M})$ and ascorbic acid $(500 \mu \mathrm{M})$ was incubated in $5 \mathrm{mM}$ HEPES buffer $(\mathrm{pH} 7.4)$ at room temperature. An aliquot of the reaction mixture was directly injected into an HPLC and CL-HPLC to determine HNE and PLPC-OOH, respectively.

Effects of chelator on HNE formation by $\mathrm{Cu}^{2+}$.

The reaction mixture containing PLPC-OOH $(500 \mu \mathrm{M}), \mathrm{Cu}^{2+}(2 \mu \mathrm{M})$ and ascorbic acid (500 $\mu \mathrm{M}$ ) was incubated with $2 \mu \mathrm{M}$ chelator for 30 minutes in $5 \mathrm{mM}$ HEPES buffer ( $\mathrm{pH} 7.4$ ) at room temperature. An aliquot of the reaction mixture was directly injected into an HPLC to determine HNE.

HNE formation from PLPC-OOH by $A \beta_{1-42^{-}} \mathrm{Cu}^{2+}$ complex. The reaction mixture containing PLPC-OOH $(500 \mu \mathrm{M})$ and ascorbic acid $(500 \mu \mathrm{M})$ was incubated with $\mathrm{Cu}^{2+}(2-8 \mu \mathrm{M})$ or $\mathrm{A} \beta_{1-42}$ $(2 \mu \mathrm{M})-\mathrm{Cu}^{2+}(2-8 \mu \mathrm{M})$ complex for 30 minutes in $5 \mathrm{mM}$ HEPES buffer $(\mathrm{pH} 7.4)$ at room 
temperature. An aliquot of the reaction mixture was directly injected into an HPLC to determine HNE.

Ascorbate-oxidase activity of $A \beta_{1-42}$ complex.

Ascorbate-oxidase activity was followed optically at $260 \mathrm{~nm}$. Reaction mixture contained 100 $\mu \mathrm{M}$ ascorbate, $22 \mu \mathrm{M} \mathrm{A} \beta_{1-42}$ and various concentrations of $\mathrm{Cu}^{2+}$ in $20 \mathrm{mM}$ HEPES buffer $(\mathrm{pH}$ 7.4). Reactions were started by the addition of ascorbate.

Effects of chelator on HNE formation by $\mathrm{AB}_{1-42}-\mathrm{Cu}^{2+}$ complex.

The reaction mixture containing PLPC-OOH $(500 \mu \mathrm{M})$, ascorbic acid $(500 \mu \mathrm{M})$ and $\mathrm{A} \beta_{1-42}(2$ $\mu \mathrm{M})-\mathrm{Cu}^{2+}(4 \mu \mathrm{M})(1: 2$ molar ratio) complex was incubated with $2 \mu \mathrm{M}$ chelator for 60 minutes in $5 \mathrm{mM}$ HEPES buffer ( $\mathrm{pH}$ 7.4) at room temperature. An aliquot of the reaction mixture was directly injected into HPLC to determine HNE.

\section{RESULTS}

Phospholipid hydroperoxide formation from PLPC by $\mathrm{AB}_{1-42-} \mathrm{Cu}^{2+}$ complex.

When synthetic phospholipid, PLPC, was incubated with both $\mathrm{Cu}^{2+}$ and ascorbic acid, the formation of phospholipid hydroperoxides was observed by CL-HPLC. The CL-HPLC chromatogram showed a main peak at $14 \mathrm{~min}$. The main peak was considered to be racemic mixture of 9-hydroperoxide and 13-hydroperoxide of linoleoyl residue (data not shown). The formation of phospholipid hydroperoxides by $\mathrm{Cu}^{2+}$ is shown in Fig. 2. The $\mathrm{Cu}^{2+}$-associated lipid peroxidation was inhibited by $A \beta_{1-42}$, when $\mathrm{Cu}^{2+}$ was bound to two molar equivalents of $A \beta_{1-42}$ (2 $\left.\mathrm{A} \beta_{1-42}-\mathrm{Cu}^{2+}\right)$. However, an equimolar complex of $\mathrm{A} \beta_{1-42}-\mathrm{Cu}^{2+}$ (1:1 molar ratio) showed phospholipid hydroperoxide formation. When the $\mathrm{Cu}^{2+}$ concentration is higher than $\mathrm{A} \beta$, the activity of phospholipid hydroperoxide formation by the complex $\left(\mathrm{A} \beta_{1-42} / \mathrm{Cu}^{2+}=1: 2\right.$, and 1:3) was higher than $\mathrm{Cu}^{2+}$. The decrease of phospholipid hydroperoxides after a 60 minute incubation is consistent with the decomposition of phospholipid hydroperoxides.

Decomposition of PLPC-OOH and formation of HNE by $\mathrm{Cu}^{2+}$.

When $500 \mu \mathrm{M}$ PLPC-OOH was incubated with both 1-3 $\mu \mathrm{M} \mathrm{Cu}^{2+}$ and $500 \mu \mathrm{M}$ ascorbic acid for 5 minutes, a decrease of PLPC-OOH and formation of HNE was observed (Fig. 3). The rates of decomposition of PLPC-OOH and HNE formation were dependent on the $\mathrm{Cu}^{2+}$ concentration. In the absence of ascorbic acid, neither decomposition of PLPC-OOH nor formation of HNE was observed (data not shown). Thus, it is likely that $\mathrm{Cu}^{2+}$ is reduced to $\mathrm{Cu}^{+}$by ascorbic acid, and that the $\mathrm{Cu}^{+}$rapidly reacts with PLPC-OOH to generate HNE (Fig. 1). The reaction was further examined at $2 \mu \mathrm{M} \mathrm{Cu}^{2+}$ and the time courses of the decrease in PLPC-OOH and the formation of HNE are shown in Fig. 4. PLPC-OOH was rapidly and almost completely decomposed during the 20 minute incubation. However, HNE continued to increase after depletion of PLPC-OOH, reaching a peak after incubation for $80 \mathrm{~min}$. The efficiency (mol \% 
yield) of the formation of HNE from decomposed PLPC-OOH after incubation for 80 minutes was $6.1 \%$.

Effects of chelators on HNE formation by $\mathrm{Cu}^{2+}$.

Figure 5 shows the amount of HNE formed from PLPC-OOH by free $\mathrm{Cu}^{2+}$ in the presence of equimolar concentration of the copper chelators. The amount of HNE formed from $500 \mu \mathrm{M}$ PLPC-OOH by incubation with $2 \mu \mathrm{M} \mathrm{Cu}^{2+}$ for 30 minutes (control) was $22.1 \mu \mathrm{M}$. The well-known $\mathrm{Cu}^{2+}$ chelator EDTA, deferoxamine, trientine, penicillamine, oxine and GHL, all inhibited the formation of $\mathrm{HNE}$ by $95,88,95,73,88$ and $96 \%$, respectively. $\mathrm{A} \beta_{1-40}$ and $\mathrm{A} \beta_{1-42}$, which are also very efficient chelators for copper, also both inhibited the formation by $92 \%$. $A \beta_{1-28}$ and $A \beta_{35-42}$ inhibited by 84 and $10 \%$, respectively. The metal chelator, clioquinol, a 5-chloro-7-iodo derivative of oxine, reported to induce a decrease in brain A $\beta$ deposition (23, 34 ), was the least effect chelator only inhibiting formation by $25 \%$. Histidine and histamine inhibited by 36 and $17 \%$, respectively. The biogenic polyamines such as putrescine, spermidine and spermine, inducers of cell growth and proliferation, reported to enhance $A \beta$-associated neurotoxicity (35), inhibited the formation by 11,18 and $11 \%$, respectively. Carnosine, a dipeptide having copper chelating property, has been reported to inhibit the oxidation of phosphatidylcholine by $\mathrm{Cu}^{2+}$ in the presence of ascorbic acid (36), but it did not show inhibitory effect.

HNE formation by $A \beta_{1-42^{-}} \mathrm{Cu}^{2+}$ complex and ascorbate-oxidase activity of $\mathrm{A} \beta_{1-42^{-}} \mathrm{Cu}^{2+}$ complex.

It has been reported that $A \beta_{1-42}$ has an ability to bind up to 3.5 molar equivalents of $\mathrm{Cu}^{2+}$ (37), and $\mathrm{A} \beta_{1-42}$ binding two molar equivalents of $\mathrm{Cu}^{2+}\left(\mathrm{A} \beta_{1-42}-2 \mathrm{Cu}^{2+}\right)$ generates hydrogen peroxide in the presence of reductant (27). $A \beta_{1-42}$ with equimolar $\mathrm{Cu}^{2+}$ decreased $\mathrm{HNE}$ formation by $91 \%$ as compared to free $\mathrm{Cu}^{2+}$ (Fig. 6A), and ascorbate-oxidase activity was also markedly inhibited (Fig. 6B). However, $\mathrm{A} \beta_{1-42}$ with two molar equivalents of $\mathrm{Cu}^{2+}$ provided a $36 \%$ inhibition of the formation by free $\mathrm{Cu}^{2+}$, and showed ascorbate-oxidase activity. The $\mathrm{A} \beta_{1-42}$ binding three molar equivalents of $\mathrm{Cu}^{2+}$ showed marked ascorbate-oxidase activity and formation of HNE, the same as shown for the formation by free $\mathrm{Cu}^{2+}$.

Effects of chelators on lipid peroxidation and $\mathrm{HNE}$ formation by $\mathrm{AB}_{1-42}-\mathrm{Cu}^{2+}$ complex.

Table 1 shows the inhibitory effect of chelators on phospholipid hydroperoxide and HNE formation by $A \beta_{1-42}-\mathrm{Cu}^{2+}$ complex. phospholipid hydroperoxide formed from PLPC by $\mathrm{A} \beta_{1-42}-\mathrm{Cu}^{2+}$ (1:1) in the presence of copper chelator was determined. The total amounts of $A \beta_{1-42}$ and copper chelators were two times higher than $\mathrm{Cu}^{2+}$. EDTA, trientine, penicillamine and GHL, markedly inhibited the formation of phospholipid hydroperoxide by $96,92,93$ and $92 \%$, respectively.

HNE formed from PLPC-OOH by $\mathrm{A} \beta_{1-42}-2 \mathrm{Cu}^{2+}(1: 2)$ in the presence of copper chelator was 
determined. The total amounts of $A \beta_{1-42}$ and copper chelators were equimolar to $\mathrm{Cu}^{2+}$. EDTA, trientine, deferoxamine, and GHL, markedly inhibited the formation of HNE by 93, 87, 82 and $87 \%$, respectively.

\section{DISCUSSION}

Lipid peroxidation is induced under conditions of oxidative stress, such as Alzheimer's disease, ischemia-reperfusion, atherosclerosis, cancer, and various other disorders. The lipid peroxidation process involves the formation of lipid hydroperoxides, HNE, and malondialdehyde (6-9). Among these products, lipid hydroperoxides, which are mainly generated from phospholipids, cholesterol esters and unsaturated fatty acids, are the intermediates of peroxidation reactions. Phospholipids are the main components of cell membranes and lipoproteins, and these are converted to phospholipid hydroperoxides under peroxidative conditions. Incubation of PLPC with free $\mathrm{Cu}^{2+}$ in the presence of ascorbic acid generated phospholipid hydroperoxides through $\mathrm{Cu}^{2+}$ reduction and peroxidation of PLPC (Fig. 2). The $\mathrm{Cu}^{2+}$-associated reactions are generally inhibited by copper chelators. Because the $\mathrm{A} \beta_{1-42}$ when binding equimolar $\mathrm{Cu}^{2+}$, forms a square-planar complex including $\mathrm{His}^{6}, \mathrm{His}^{13}$, $\mathrm{His}^{14}$, and $\mathrm{N}$-terminal amino group (21), the equimolar complex $\left(\mathrm{A} \beta_{1-42}-\mathrm{Cu}^{2+}\right)$ was expected to be redox-inactive. However, the $\mathrm{A} \beta_{1-42}-\mathrm{Cu}^{2+}$ was not redox-inactive, and showed phospholipid hydroperoxide formation (Fig. 2), and this is the first evidence for phospholipid hydroperoxide formation by $\mathrm{A} \beta_{1-42}-\mathrm{Cu}^{2+}$ complex. Two molar equivalents of $\mathrm{A} \beta_{1-42}$ showed $\mathrm{Cu}^{2+}$-associated lipid peroxidation but to a lesser extent. On the other hand, when $\mathrm{Cu}^{2+}$ concentration is higher than $A \beta_{1-42}$, the complexes $\left(A \beta_{1-42}-2 \mathrm{Cu}^{2+}\right.$ and $\left.A \beta_{1-42}-3 \mathrm{Cu}^{2+}\right)$ showed higher lipid peroxidation compared to free $\mathrm{Cu}^{2+}$, and the formed phospholipid hydroperoxide was reduced after incubation for 60 minutes (Fig. 2). The decrease in formed phospholipid hydroperoxide was caused by the reaction of phospholipid hydroperoxides with the complexes as mentioned below.

The reaction of one of the phospholipid hydroperoxides, PLPC-OOH, with hemoprotein has demonstrated the rapid formation of HNE (18). Reaction of ferric ion with PLPC-OOH is very slow and no HNE formation has been observed (18). In the presence of ascorbic acid as reductant, the reaction was also very slow (unpublished result). In the absence of ascorbic acid, reaction of $\mathrm{Cu}^{2+}$ with PLPC-OOH proceeds also very slowly (data not shown). On the other hand, in the presence of ascorbic acid, $\mathrm{Cu}^{2+}$ was reduced to $\mathrm{Cu}^{+}$, and rapidly reacted with PLPC-OOH, followed by a generation of HNE (Figs. 3 and 6). The reaction was dependent on both the concentration of $\mathrm{Cu}^{2+}$ and the ascorbate-oxidase activity.

The time-courses of the decomposition of PLPC-OOH and HNE formation by $2 \mu \mathrm{M} \mathrm{Cu}^{2+}$ are shown in Fig. 4. In this reaction, over 99\% of the added PLPC-OOH decomposed after incubation for 20 minutes; however, the increase in HNE concentration continued for more than 
20 minutes. The increase in HNE after depletion of PLPC-OOH has been previously observed in the case of HNE formation by methemoglobin (18). These data suggest the operation of more than one pathway that generates HNE from PLPC-OOH - one pathway that rapidly generates a burst of product and another pathway that generates HNE more slowly, probably from a stable unidentified intermediate. The maximum efficiency (mol\% yield) of the formation of HNE from decomposed PLPC-OOH, shown after incubation for 80 minutes, was $6.1 \%$, and was higher than that by methemoglobin (1.6\%) (18). $\mathrm{Cu}^{2+}$-associated decomposition of phospholipid hydroperoxides may be an important mechanism for HNE formation in vivo.

Transition metal-associated reactions are generally inhibited by metal chelators. GHL, known as a growth-modulating tripeptide isolated from human serum, is very efficient chelator for copper $(38,39)$. Because the GHL- $\mathrm{Cu}^{2+}$ forms a planar tridentate complex involving the imino nitrogen of the histidyl imidazole ring (38), $\mathrm{Cu}^{2+}$-associated $\mathrm{HNE}$ formation from PLPC-OOH was considered to be markedly inhibited (Fig. 5). The $A \beta_{1-28}, A \beta_{1-40}$ and $A \beta_{1-42}$ when binding equimolar $\mathrm{Cu}^{2+}$, forms a square-planar complex (21). The formation of HNE by these equimolar complexes was also markedly inhibited. In contrast, $A \beta_{35-42}$ having no $\mathrm{Cu}^{2+}$-binding site did not inhibit the formation of HNE. These data indicate that the formation of equimolar complexes of $\mathrm{Cu}^{2+}$ with $\mathrm{A} \beta$ is necessary for inhibition of $\mathrm{Cu}^{2+}$-associated HNE formation from PLPC-OOH.

It has been reported that $A \beta_{1-42}$ has an ability to bind up to 3.5 molar equivalents of $\mathrm{Cu}^{2+}(37)$. $\mathrm{A} \beta_{1-42}$ binding two molar equivalents of $\mathrm{Cu}^{2+}\left(\mathrm{A} \beta_{1-42}-2 \mathrm{Cu}^{2+}\right)$ showed reduced ascorbate-oxidase activity inhibited the formation of HNE, corresponding to about $60 \%$ of the formation by free $\mathrm{Cu}^{2+}$ (Fig. 6). Ascorbate radicals were observed during ascorbate-oxidase reaction by $\mathrm{A} \beta_{1-42}-2 \mathrm{Cu}^{2+}$ (data not shown). On the other hand, three molar equivalents of $\mathrm{Cu}^{2+}$ $\left(\mathrm{A} \beta_{1-42-3} \mathrm{Cu}^{2+}\right)$ was equivalent to free $\mathrm{Cu}^{2+}$ suggesting an overload of inhibition. In this regard, Opazo et al. reported that $A \beta_{1-42}$ purified from Alzheimer's disease plaque binds two molar equivalents of $\mathrm{Cu}^{2+}$, and it acts as pro-oxidant to generate hydrogen peroxide in the presence of reductant (27). The $\mathrm{A} \beta_{1-42}-2 \mathrm{Cu}^{2+}$ and $\mathrm{A} \beta_{1-42-3 \mathrm{Cu}^{2+}}$ generated hydrogen peroxide in the presence of ascorbate much the same as ascorbate-oxidase activity and HNE formation (unpublished result). These data indicate that the complex of $\mathrm{Cu}^{2+}$ with $\mathrm{A} \beta$ acts as a pro-oxidant when $\mathrm{Cu}^{2+}$ concentration is higher than $A \beta_{1-42}$. On the other hand, the generation of hydrogen peroxide by free $\mathrm{Cu}^{2+}$ in the presence of ascorbate as reductant was inhibited by equimolar $A \beta_{1-42}$ (unpublished result) and lipid peroxidation by $\mathrm{Cu}^{2+}$ was inhibited by two molar equivalent of $A \beta_{1-42}$ (Fig. 2). These data indicate that $A \beta_{1-42}$ acts as antioxidant when $\mathrm{Cu}^{2+}$ concentrations are lower than $A \beta_{1-42}$. Such an antioxidant effect of $A \beta$ is not completely surprising. Kontush et al. documented the in vitro effect of $\mathrm{A} \beta$ as antioxidant on $\mathrm{Cu}^{2+}$-catalyzed oxidation of low density lipoprotein when added in molar excess of $\mathrm{Cu}^{2+}(40)$. Nunomura et al. reported that increases of $\mathrm{A} \beta$ in vivo are associated with decreased oxidative damage (41). Based on data presented here, 
we suspect that $\mathrm{A} \beta$ acts primarily as antioxidant to prevent $\mathrm{Cu}^{2+}$-catalyzed oxidation of biomolecules in the brain at low concentrations of $\mathrm{Cu}^{2+}$. On the other hand, at higher concentrations of $\mathrm{Cu}^{2+}$ than $\mathrm{A} \beta_{1-42}, \mathrm{~A} \beta_{1-42}-\mathrm{Cu}^{2+}$ (1:1) shows phospholipid hydroperoxide formation, and furthermore, $A \beta_{1-42}-2 \mathrm{Cu}^{2+}$ (1:2) and $\mathrm{A} \beta_{1-42}-3 \mathrm{Cu}^{2+}$ (1:3) show both phospholipid hydroperoxide and HNE formations. As such, both antioxidant and pro-oxidant properties of the $\mathrm{A} \beta$ complex with $\mathrm{Cu}^{2+}$ are dependent on the ratio of $\mathrm{Cu}^{2+}$ to $\mathrm{A} \beta$.

The phospholipid hydroperoxide formation by $\mathrm{A} \beta_{1-42}-\mathrm{Cu}^{2+}$ (1:1) was markedly inhibited by copper chelators such as EDTA, trientine, penicillamine and GHL (Table 1). The HNE formation was also markedly inhibited by copper chelators such as EDTA, trientine, deferoxamine and GHL. These data indicated that the oxidative stress by the complex of $A \beta$ with $\mathrm{Cu}^{2+}$ in the brain of Alzheimer's disease may be abrogated by copper chelator treatment.

The copper ion is considered to be mainly bound to copper-chelating protein such as ceruloplasmin and metallothionein in vivo (42). Bound copper, similar to $\mathrm{Cu}^{2+}$ of $\mathrm{A} \beta_{1-42}-2 \mathrm{Cu}^{2+}$ (Fig. 6), carnosine- $\mathrm{Cu}^{2+}$ and polyamines- $\mathrm{Cu}^{2+}$ (Fig. 5) in this study, is assumed to be redox-active, and may induce HNE formation from lipid hydroperoxides in vivo. The mechanism of the formation of HNE in vivo has been a long-standing question. The reaction of $\mathrm{Cu}^{+}$, generated by reduction of binding $\mathrm{Cu}^{2+}$, with lipid hydroperoxides may be one of a possible route of HNE formation in vivo.

Acknowledgements - This work was supported in part by a grant from Yuasa Memorial Foundation.

\section{REFERENCES}

[1] Smith, M. A.; Perry, G..; Richey. P. L.; Sayre, L. M.; Anderson, V. E.; Beal M. F.; Kowall, N. Oxidative damage in Alzheimer's. Nature 382:120-121; 1996.

[2] Nunomura, A.; Perry, G.; Aliev, G.; Hirai K.; Takeda, A.; Balraj, E. K.; Jones, P. K.; Ghanbari, H.; Wataya, T.; Shimohama, S.; Chiba, S.; Atwood, C. S.; Petersen, R. B.; Smith, M. A. Oxidative damage is the earliest event in Alzheimer disease. J. Neuropathol. Exp. Neurol. 60:759-767; 2001.

[3] Varadarajan, S.; Yatin, S.; Aksenova, M.; Butterfield, D. A. Review: Alzheimer's amyloid beta-peptide-associated free radical oxidative stress and neurotoxicity. J. Struct. Biol. 130:184-208; 2000.

[4] Kontush, A. Amyloid-beta: an antioxidant that becomes a pro-oxidant and critically contributes to Alzheimer's disease. Free Radic. Biol. Med. 31:1120-1131; 2001.

[5] Atwood, C. S.; Obrenovich, M. E.; Liu, T.; Chan, H.; Perry, G.; Smith, M. A.; Martins, R. N. 
Amyloid-beta: a chameleon walking in two worlds: a review of the trophic and toxic properties of amyloid-beta. Brain Res. Brain Res. Rev. 43:1-16; 2003.

[6] Girotti, A.W. Lipid hydroperoxide generation, turnover, and effector action in biological systems. J. Lipid Res. 39:1529-1542; 1998.

[7] Miyazawa, T.; Fujimoto, K.; Suzuki, T.; Yasuda, K. Determination of phospholipid hydroperoxides using luminol chemiluminescence--high-performance liquid chromatography. Methods Enzymol. 233:324-332; 1994.

[8] Esterbauer, H.; Schaur, R. J.; Zollner, H. Chemistry and biochemistry of 4-hydroxynonenal, malonaldehyde and related aldehydes. Free Radic. Biol. Med. 11:81-128; 1991.

[9] Parola, M.; Bellomo, G.; Robino, G.; Barrera, G.; Dianzani, M. U. 4-Hydroxynonenal as a biological signal: molecular basis and pathophysiological implications. Antioxid. Redox Signal. 1:255-284; 1999.

[10] Spiteller, P.; Kern, W.; Reiner, J.; Spiteller, G. Aldehydic lipid peroxidation products derived from linoleic acid. Biochim. Biophys. Acta 1531:188-208; 2001.

[11] Mark, R. J.; Lovell, M. A.; Markesbery, W, R.; Uchida, K.; Mattson, M. P. A role for 4-hydroxynonenal, an aldehydic product of lipid peroxidation, in disruption of ion homeostasis and neuronal death induced by amyloid beta-peptide. J. Neurochem. 68:255-264; 1997.

[12] Butterfield, D.A.; Castegna. A.; Lauderback, C. M.; Drake, J. Evidence that amyloid beta-peptide-induced lipid peroxidation and its sequelae in Alzheimer's disease brain contribute to neuronal death. Neurobiol. Aging. 23:655-664; 2002.

[13] Rabacchi, S. A.; Friedman, W. J.; Shelanski, M. L.; Troy, C. M. Divergence of the apoptotic pathways induced by 4-hydroxynonenal and amyloid beta-protein. Neurobiol Aging. 25:1057-1066; 2004.

[14] Keller, J. N.; Hanni, K. B.; Markesbery, W. R. 4-hydroxynonenal increases neuronal susceptibility to oxidative stress. J. Neurosci. Res. 58:823-830; 1999.

[15] Ando, Y.; Brannstrom, T.; Uchida, K.; Nyhlin, N.; Nasman, B.; Suhr, O.; Yamashita, T.; Olsson, T.; El Salhy, M.; Uchino, M.; Ando, M. Histochemical detection of 4-hydroxynonenal protein in Alzheimer amyloid. J. Neurol. Sci. 156:172-176; 1998.

[16] Sayre, L. M.; Zelasko, D. A.; Harris, P. L.; Perry, G.; Salomon, R. G.; Smith, M. A. 4-Hydroxynonenal-derived advanced lipid peroxidation end products are increased in Alzheimer's disease. J. Neurochem. 68:2092-2097; 1997.

[17] Takeda, A.; Smith, M. A.; Avila, J.; Nunomura, A.; Siedlak, S. L.; Zhu, X.; Perry, G.; Sayre, L. M. In Alzheimer's disease, heme oxygenase is coincident with Alz50, an epitope of tau induced by 4-hydroxy-2-nonenal modification. J. Neurochem. 75:1234-1241; 2000.

[18] Hayashi, T.; Uchida, K.; Takebe, G.; Takahashi, K. Rapid formation of 4-hydroxy-2-nonenal, malondialdehyde, and phosphatidylcholine aldehyde from phospholipid 
hydroperoxide by hemoproteins. Free Radic. Biol. Med. 36:1025-1033; 2004.

[19] Dong, J.; Atwood, C. S.; Anderson, V. E.; Siedlak, S. L.; Smith, M. A.; Perry, G.; Carey, P. R. Metal binding and oxidation of amyloid-beta within isolated senile plaque cores: Raman microscopic evidence. Biochemistry 42:2768-2773; 2003.

[20] Atwood, C. S.; Moir, R. D.; Huang, X.; Scarpa, R. C.; Bacarra, N. M.; Romano, D. M.; Hartshorn, M. A.; Tanzi, R. E.; Bush, A. I. Dramatic aggregation of Alzheimer abeta by $\mathrm{Cu}(\mathrm{II})$ is induced by conditions representing physiological acidosis. J. Biol. Chem. 273:12817-12826; 1998.

[21] Syme, C. D.; Nadal, R. C.; Rigby, S. E.; Viles, J. H. Copper binding to the amyloid-beta (Abeta) peptide associated with Alzheimer's disease: folding, coordination geometry, $\mathrm{pH}$ dependence, stoichiometry, and affinity of Abeta-(1-28): insights from a range of complementary spectroscopic techniques. J. Biol. Chem. 279:18169-18177; 2004.

[22] Miura, T.; Suzuki, K.; Kohata, N.; Takeuchi, H. Metal binding modes of Alzheimer's amyloid beta-peptide in insoluble aggregates and soluble complexes. Biochemistry 39:7024-7031; 2000.

[23] Bush, A. I. The metallobiology of Alzheimer's disease. Trends Neurosci. 26:207-214; 2003.

[24] Rottkamp, C. A.; Raina, A. K.; Zhu, X.; Gaier, E.; Bush, A. I.; Atwood, C. S.; Chevion, M.; Perry, G.; Smith, M. A. Redox-active iron mediates amyloid-beta toxicity. Free Radic. Biol. Med. 30:447-450; 2001.

[25] Huang, X.; Atwood, C. S.; Hartshorn M. A.; Multhaup, G.; Goldstein, L. E.; Scarpa, R. C.; Cuajungco, M. P.; Gray, D. N.; Lim, J.; Moir, R. D.; Tanzi, R. E.; Bush, A. I. The A beta peptide of Alzheimer's disease directly produces hydrogen peroxide through metal ion reduction. Biochemistry 38:7609-7616; 1999.

[26] Huang, X.; Cuajungco, M. P.; Atwood, C. S.; Hartshorn, M. A.; Tyndall, J. D.; Hanson, G. R.; Stokes, K. C.; Leopold, M.; Multhaup, G.; Goldstein, L. E.; Scarpa, R. C.; Saunders, A. J.; Lim, J.; Moir, R. D.; Glabe, C.; Bowden, E. F.; Masters, C. L.; Fairlie, D. P.; Tanzi, R. E.; Bush, A. I. $\mathrm{Cu}$ (II) potentiation of alzheimer abeta neurotoxicity. Correlation with cell-free hydrogen peroxide production and metal reduction. J. Biol. Chem. 274:37111-37116; 1999.

[27] Opazo, C.; Huang, X.; Cherny, R. A.; Moir, R. D.; Roher, A. E.; White, A. R.; Cappai, R.; Masters, C. L.; Tanzi, R. E.; Inestrosa, N. C.; Bush, A. I. Metalloenzyme-like activity of Alzheimer's disease beta-amyloid. Cu-dependent catalytic conversion of dopamine, cholesterol, and biological reducing agents to neurotoxic H2O2. J. Biol. Chem. 277:40302-40308; 2002.

[28] Koudinov, A. R.; Koudinova, N. V.; Kumar, A.; Beavis, R. C.; Ghiso, J. Biochemical characterization of Alzheimer's soluble amyloid beta protein in human cerebrospinal fluid: association with high density lipoproteins. Biochem. Biophys. Res. Commun. 223:592-597; 1996. 
[29] Koudinov, A.; Matsubara, E.; Frangione, B.; Ghiso, J. The soluble form of Alzheimer's amyloid beta protein is complexed to high density lipoprotein 3 and very high density lipoprotein in normal human plasma. Biochem. Biophys. Res. Commun. 205:1164-1171; 1994.

[30] Prasad, M. R.; Lovell, M. A.; Yatin, M.; Dhillon, H.; Markesbery, W. R. Regional membrane phospholipid alterations in Alzheimer's disease. Neurochem. Res. 23:81-88; 1998.

[31] Schippling, S.; Kontush, A.; Arlt, S.; Buhmann, C.; Sturenburg, H. J.; Mann, U.; Muller-Thomsen, T.; Beisiegel, U. Increased lipoprotein oxidation in Alzheimer's disease. Free Radic. Biol. Med. 28:351-360; 2000.

[32] Hayashi, T.; Miyazawa, T. Age-associated oxidative damage in microsomal and plasma membrane lipids of rat hepatocytes. Mech. Ageing Dev. 100:231-242; 1998.

[33] Saito, Y.; Hayashi, T.; Tanaka, A.; Watanabe, Y.; Suzuki, M.; Saito, E.; Takahashi, K. Selenoprotein $\mathrm{P}$ in human plasma as an extracellular phospholipid hydroperoxide glutathione peroxidase. Isolation and enzymatic characterization of human selenoprotein P. J. Biol. Chem. 274:2866-2871; 1999.

[34] Cherny, R. A.; Atwood, C. S.; Xilinas, M. E.; Gray, D. N.; Jones, W. D.; McLean, C. A.; Barnham, K. J.; Volitakis, I.; Fraser, F. W.; Kim, Y.; Huang, X.; Goldstein, L. E.; Moir, R. D.; Lim, J. T.; Beyreuther, K.; Zheng, H.; Tanzi, R. E.; Masters, C. L.; Bush, A. I. Treatment with a copper-zinc chelator markedly and rapidly inhibits beta-amyloid accumulation in Alzheimer's disease transgenic mice. Neuron 30:665-676; 2001.

[35] Yatin, S. M.; Yatin, M.; Varadarajan, S.; Ain, K. B.; Butterfield, D. A. Role of spermine in amyloid beta-peptide-associated free radical-induced neurotoxicity. J. Neurosci. Res. 63:395-401; 2001.

[36] Decker, E. A.; Livisay, S. A.; Zhou, S. A re-evaluation of the antioxidant activity of purified carnosine. Biochemistry (Mosc) 65:766-770; 2000.

[37] Atwood, C. S.; Scarpa, R. C.; Huang, X.; Moir, R. D.; Jones, W. D.; Fairlie, D. P.; Tanzi, R. E.; Bush, A. I. Characterization of copper interactions with alzheimer amyloid beta peptides: identification of an attomolar-affinity copper binding site on amyloid beta1-42. J. Neurochem. 75:1219-1233; 2000.

[38] Pickart, L.; Freedman, J. H.; Loker, W. J.; Peisach, J.; Perkins, C. M.; Stenkamp, R. E.; Weinstein, B. Growth-modulating plasma tripeptide may function by facilitating copper uptake into cells. Nature 288:715-717; 1980.

[39] Freedman, J. H.; Pickart, L.; Weinstein, B.; Mims, W. B.; Peisach, J. Structure of the Glycyl-L-histidyl-L-lysine--copper(II) complex in solution. Biochemistry 21:4540-4544; 1982.

[40] Kontush, A.; Berndt, C.; Weber, W.; Akopyan, V.; Arlt, S.; Schippling, S.; Beisiegel, U. Amyloid-beta is an antioxidant for lipoproteins in cerebrospinal fluid and plasma. Free Radic. Biol. Med. 30:119-128; 2001. 
[41] Nunomura, A.; Perry, G.; Aliev, G.; Hirai, K.; Takeda, A.; Balraj, E. K.; Jones, P. K.; Ghanbari, H.; Wataya, T.; Shimohama, S.; Chiba, S.; Atwood, C. S.; Petersen, R. B.; Smith, M. A. Oxidative damage is the earliest event in Alzheimer disease. J. Neuropathol. Exp. Neurol. 60:759-767; 2001.

[42] Koizumi, M.; Fujii, J.; Suzuki, K.; Inoue, T.; Inoue, T.; Gutteridge. J. M.; Taniguchi, N. A marked increase in free copper levels in the plasma and liver of LEC rats: an animal model for Wilson disease and liver cancer. Free Radic. Res. 28:441-450; 1998.

\author{
ABBREVIATIONS \\ HNE - 4-hydroxy-2-nonenal \\ $\mathrm{A} \beta$ - amyloid-beta peptide \\ PLPC - 1-palmitoyl-2-linoleoyl phosphatidylcholine \\ PLPC-OOH- 1-palmitoyl-2-(13-hydroperoxy-cis-9, trans-11-octadecadienoyl) \\ phosphatidylcholine \\ GHL — glycyl-L-histidyl-L-lysine \\ CL-HPLC — chemiluminescence detection-high performance liquid chromatography
}

Figure legends

\title{
Fig. 1. HNE formation from PLPC.
}

Fig. 2. Phospholipid hydroperoxide formation from PLPC by $\mathbf{A} \beta_{1-42}-\mathbf{C u}^{2+}$ complex. The reaction mixture containing PLPC $(1 \mathrm{mM})$ and ascorbic acid $(2 \mathrm{mM})$ was incubated with $\mathrm{Cu}^{2+}$ $(10 \mu \mathrm{M})$ or $\mathrm{A} \beta_{1-42}(3.3 \sim 20 \mu \mathrm{M})-\mathrm{Cu}^{2+}(10 \mu \mathrm{M})$ complex in $5 \mathrm{mM}$ HEPES buffer $(\mathrm{pH} 7.4)$ at room temperature. An aliquot of the reaction mixture was directly injected into a CL-HPLC to determine phospholipid hydroperoxide. Each point represents the mean \pm S.D. of three experiments.

Fig. 3. $\mathrm{Cu}^{2+}$-dependent decomposition of PLPC-OOH and the formation of HNE from PLPC-OOH in the presence of ascorbic acid. $500 \mu \mathrm{M}$ PLPC-OOH and $500 \mu \mathrm{M}$ ascorbic acid was incubated with 1-3 $\mu \mathrm{M} \mathrm{Cu}^{2+}$ for 5 minutes in 5 mM HEPES buffer ( $\mathrm{pH}$ 7.4). An aliquot of the reaction mixture was directly injected into a CL-HPLC and HPLC to determine PLPC-OOH and $\mathrm{HNE}$, respectively. Each point represents the mean \pm S.D. of three experiments.

Fig. 4. Time courses of the decomposition of PLPC-OOH and the formation of HNE 
from PLPC-OOH by $\mathrm{Cu}^{2+}$ in the presence of ascorbic acid. $500 \mu \mathrm{M}$ PLPC-OOH and 500 $\mu \mathrm{M}$ ascorbic acid was incubated with $2 \mu \mathrm{M} \mathrm{Cu}^{2+}$ in $5 \mathrm{mM}$ HEPES buffer ( $\mathrm{pH}$ 7.4). An aliquot of the reaction mixture was directly injected into a CL-HPLC and HPLC to determine PLPC-OOH and HNE, respectively. Each point represents the mean \pm S.D. of three experiments.

Fig. 5. Effects of chelators on the formation of $\mathrm{HNE}$ from PLPC-OOH by $\mathrm{Cu}^{2+}$ and ascorbic acid. $500 \mu \mathrm{M}$ PLPC-OOH, $500 \mu \mathrm{M}$ ascorbic acid and $2 \mu \mathrm{M} \mathrm{Cu}^{2+}$ was incubated with 2 $\mu \mathrm{M}$ chelator for 30 minutes in $5 \mathrm{mM}$ HEPES buffer ( $\mathrm{pH}$ 7.4). An aliquot of the reaction mixture was directly injected into an HPLC to determine HNE. Each point represents the mean \pm S.D. of three experiments.

Fig. 6. Effects of ratio of $\mathrm{Cu}^{2+}$ to $\mathrm{A}_{1-42}$ on $\mathrm{Cu}^{2+}$-dependent formation of $\mathrm{HNE}$ and ascorbate-oxidase activity. (A) $500 \mu \mathrm{M}$ PLPC-OOH and $500 \mu \mathrm{M}$ ascorbic acid was incubated with $\mathrm{A} \beta_{1-42}(2 \mu \mathrm{M})-\mathrm{Cu}^{2+}(2-8 \mu \mathrm{M})(\mathrm{O})$ for 30 minutes in 5 mM HEPES buffer ( $\mathrm{pH}$ 7.4). Closed circle $(\bullet)$ represent $\mathrm{HNE}$ formation by $\mathrm{Cu}^{2+}$ alone $(2-8 \mu \mathrm{M})$ which concentration are the same as those of $\mathrm{A} \beta_{1-42}-\mathrm{Cu}^{2+}$ complex. An aliquot of the reaction mixture was directly injected into an HPLC to determine HNE. Each point represents the mean \pm S.D. of three experiments. (B) Reaction mixture contained $100 \mu \mathrm{M}$ ascorbate, $22 \mu \mathrm{MA} \beta_{1-42}$ and various concentrations of $\mathrm{Cu}^{2+}$ (○) in 20mM HEPES buffer ( $\mathrm{pH}$ 7.4). Reactions were started by the addition of ascorbate. Ascorbate-oxidase activity was followed optically at $260 \mathrm{~nm}$. Each point represents the mean of three experiments.

Table 1.

Effects of chelators on phospholipid hydroperoxide and $\mathrm{HNE}$ formations by $\mathrm{A} \beta_{1-42}-\mathrm{Cu}^{2+}$ complex.

a. The reaction mixture containing PLPC $(1 \mathrm{mM})$, ascorbic acid $(2 \mathrm{mM})$ and $\mathrm{A} \beta_{1-42}(10 \mu \mathrm{M})$ $\mathrm{Cu}^{2+}(10 \mu \mathrm{M})(1: 1$ molar ratio) complex was incubated with $10 \mu \mathrm{M}$ chelator for 60 minutes in 5 $\mathrm{mM}$ HEPES buffer ( $\mathrm{pH}$ 7.4) at room temperature. An aliquot of the reaction mixture was directly injected into a CL-HPLC to determine phospholipid hydroperoxide.

b. The reaction mixture containing PLPC-OOH $(500 \mu \mathrm{M})$, ascorbic acid $(500 \mu \mathrm{M})$ and $\mathrm{A} \beta_{1-42}$ $(2 \mu \mathrm{M})-\mathrm{Cu}^{2+}(4 \mu \mathrm{M})(1: 2$ molar ratio) complex was incubated with $2 \mu \mathrm{M}$ chelator for 60 minutes in $5 \mathrm{mM}$ HEPES buffer ( $\mathrm{pH} \mathrm{7.4)}$ ) at room temperature. An aliquot of the reaction mixture was directly injected into an HPLC to determine HNE.

Each value represents the mean of three experiments. 
Fig. 1. HNE formation from PLPC.

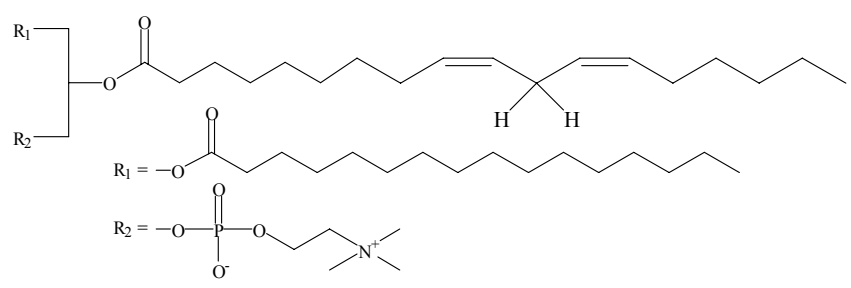

PLPC (1-palmitoyl-2-linoleoyl phosphatidylcholine)
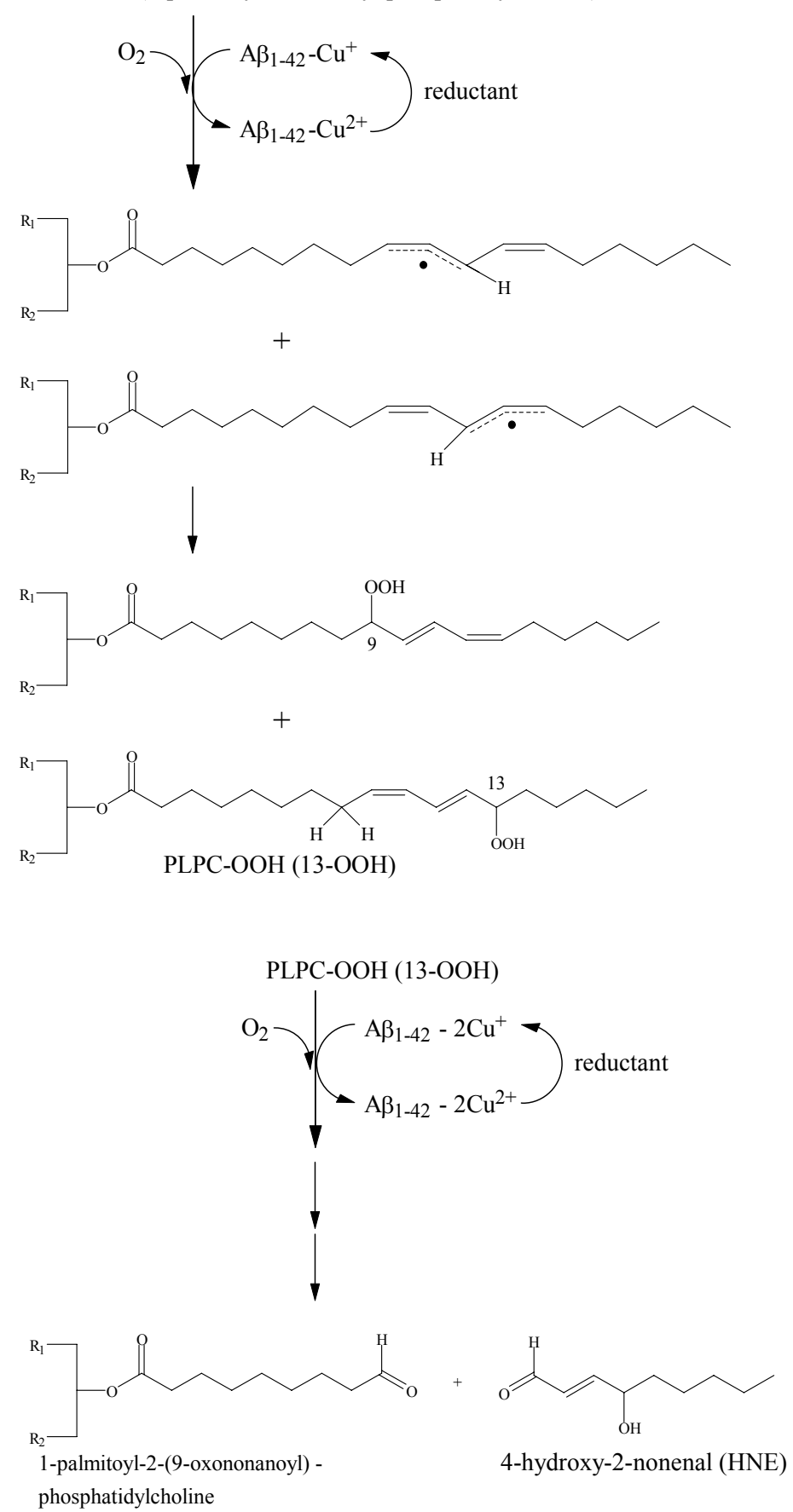
Fig. 2. Phospholipid hydroperoxide formation from PLPC by $\mathbf{A} \beta_{1-42}-\mathbf{C u}^{2+}$ complex. The reaction mixture containing PLPC $(1 \mathrm{mM})$ and ascorbic acid $(2 \mathrm{mM})$ was incubated with $\mathrm{Cu}^{2+}$ $(10 \mu \mathrm{M})$ or $\mathrm{A} \beta_{1-42}(3.3 \sim 20 \mu \mathrm{M})-\mathrm{Cu}^{2+}(10 \mu \mathrm{M})$ complex in $5 \mathrm{mM}$ HEPES buffer $(\mathrm{pH} 7.4)$ at room temperature. An aliquot of the reaction mixture was directly injected into a CL-HPLC to determine phospholipid hydroperoxide. Each point represents the mean \pm S.D. of three experiments.

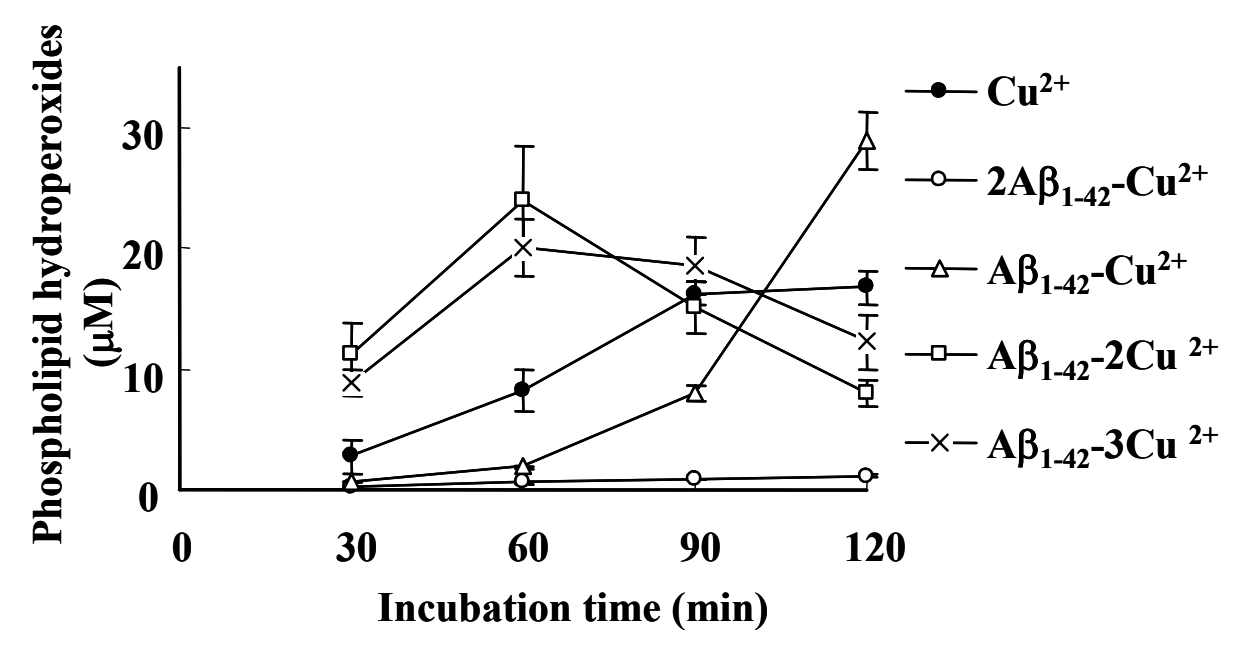


Fig. 3. $\mathrm{Cu}^{2+}$-dependent decomposition of PLPC-OOH and the formation of $\mathrm{HNE}$ from PLPC-OOH in the presence of ascorbic acid. $500 \mu \mathrm{M}$ PLPC-OOH and $500 \mu \mathrm{M}$ ascorbic acid was incubated with 1-3 $\mu \mathrm{M} \mathrm{Cu}^{2+}$ for 5 minutes in 5 mM HEPES buffer ( $\mathrm{pH}$ 7.4). An aliquot of the reaction mixture was directly injected into a CL-HPLC and HPLC to determine PLPC-OOH and $\mathrm{HNE}$, respectively. Each point represents the mean \pm S.D. of three experiments.

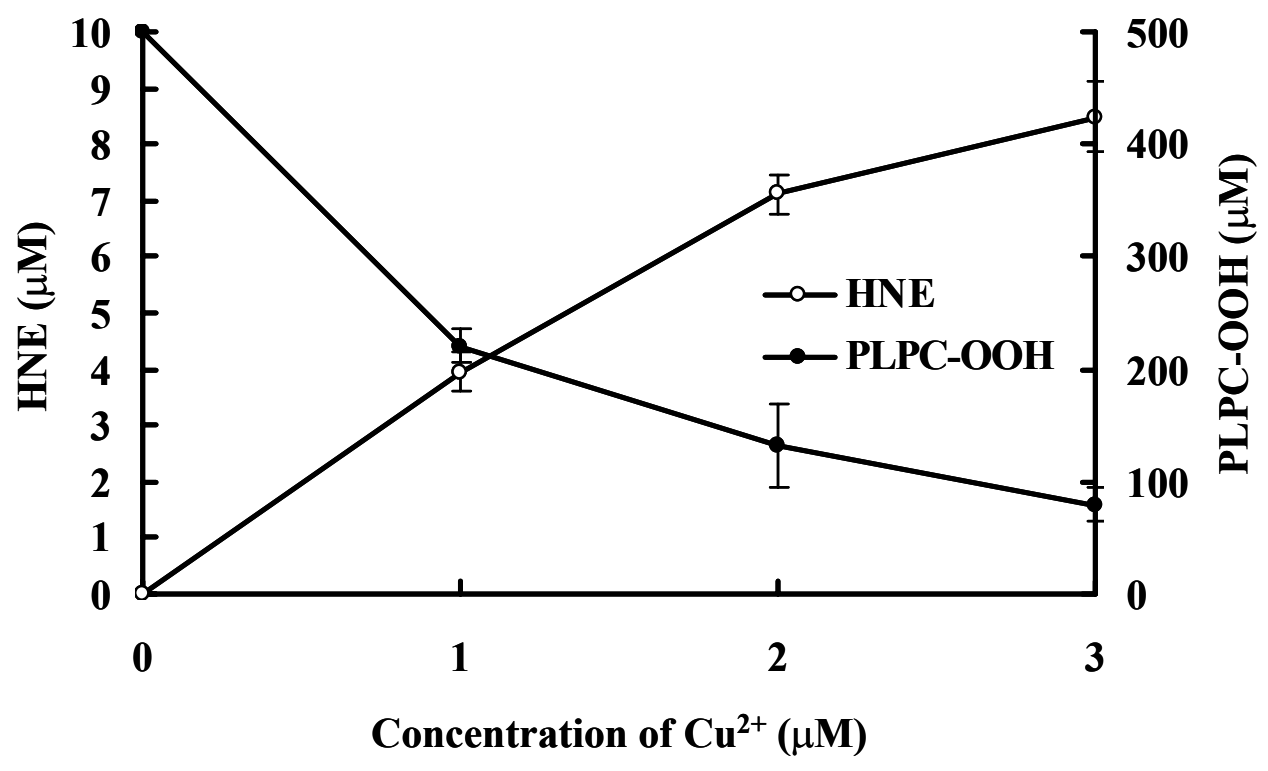


Fig. 4. Time courses of the decomposition of PLPC-OOH and the formation of HNE from PLPC-OOH by $\mathrm{Cu}^{2+}$ in the presence of ascorbic acid. $500 \mu \mathrm{M}$ PLPC-OOH and 500 $\mu \mathrm{M}$ ascorbic acid was incubated with $2 \mu \mathrm{M} \mathrm{Cu}^{2+}$ in $5 \mathrm{mM}$ HEPES buffer ( $\mathrm{pH}$ 7.4). An aliquot of the reaction mixture was directly injected into a CL-HPLC and HPLC to determine PLPC-OOH and HNE, respectively. Each point represents the mean \pm S.D. of three experiments.

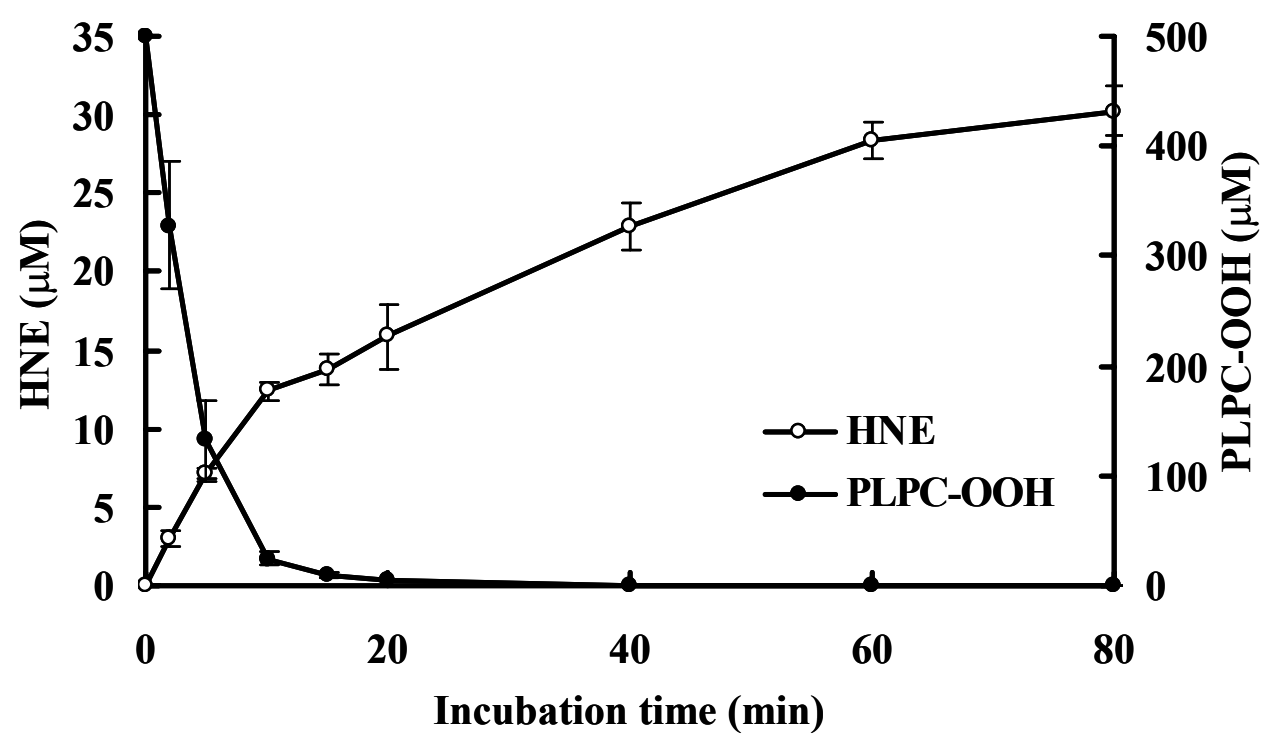


Fig. 5. Effects of chelators on the formation of $\mathrm{HNE}$ from PLPC-OOH by $\mathrm{Cu}^{2+}$ and ascorbic acid. $500 \mu \mathrm{M}$ PLPC-OOH, $500 \mu \mathrm{M}$ ascorbic acid and $2 \mu \mathrm{M} \mathrm{Cu}^{2+}$ was incubated with 2 $\mu \mathrm{M}$ chelator for 30 minutes in $5 \mathrm{mM}$ HEPES buffer ( $\mathrm{pH}$ 7.4). An aliquot of the reaction mixture was directly injected into an HPLC to determine HNE. Each point represents the mean \pm S.D. of three experiments.

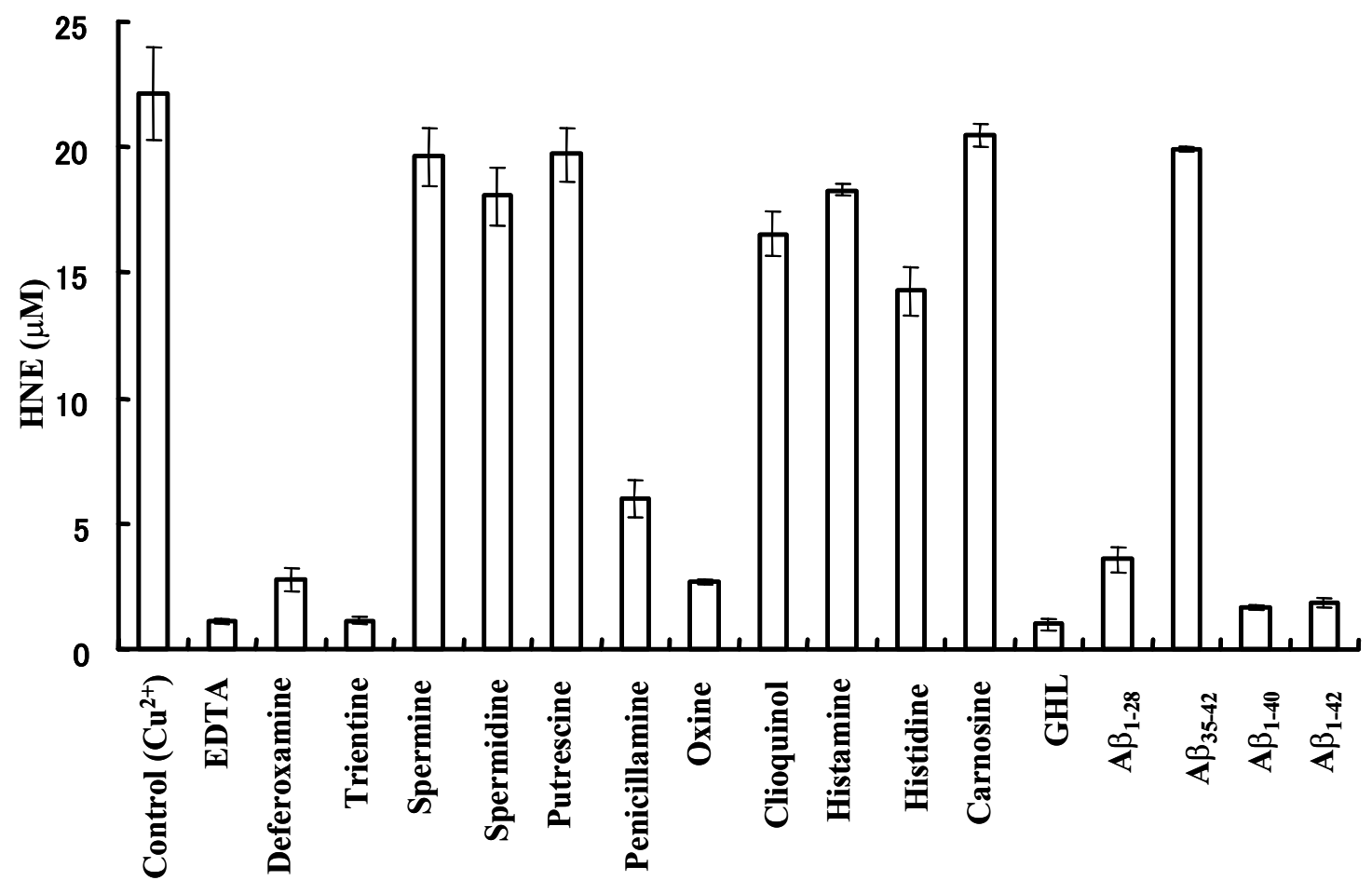


Fig. 6. Effects of ratio of $\mathrm{Cu}^{2+}$ to $\mathrm{A \beta}_{1-42}$ on $\mathrm{Cu}^{2+}$-dependent formation of $\mathrm{HNE}$ and ascorbate-oxidase activity. (A) $500 \mu \mathrm{M}$ PLPC-OOH and $500 \mu \mathrm{M}$ ascorbic acid was incubated with $\mathrm{A} \beta_{1-42}(2 \mu \mathrm{M})-\mathrm{Cu}^{2+}(2-8 \mu \mathrm{M})(0)$ for 30 minutes in $5 \mathrm{mM}$ HEPES buffer (pH 7.4). Closed circle $(\bullet)$ represent $\mathrm{HNE}$ formation by $\mathrm{Cu}^{2+}$ alone $(2-8 \mu \mathrm{M})$ which concentration are the same as those of $\mathrm{A} \beta_{1-42}-\mathrm{Cu}^{2+}$ complex. An aliquot of the reaction mixture was directly injected into an HPLC to determine HNE. Each point represents the mean \pm S.D. of three experiments. (B) Reaction mixture contained $100 \mu \mathrm{M}$ ascorbate, $22 \mu \mathrm{M} A \beta_{1-42}$ and various concentrations of $\mathrm{Cu}^{2+}$ (०) in 20mM HEPES buffer ( $\mathrm{pH} 7.4$ ). Reactions were started by the addition of ascorbate. Ascorbate-oxidase activity was followed optically at $260 \mathrm{~nm}$. Each point represents the mean of three experiments.
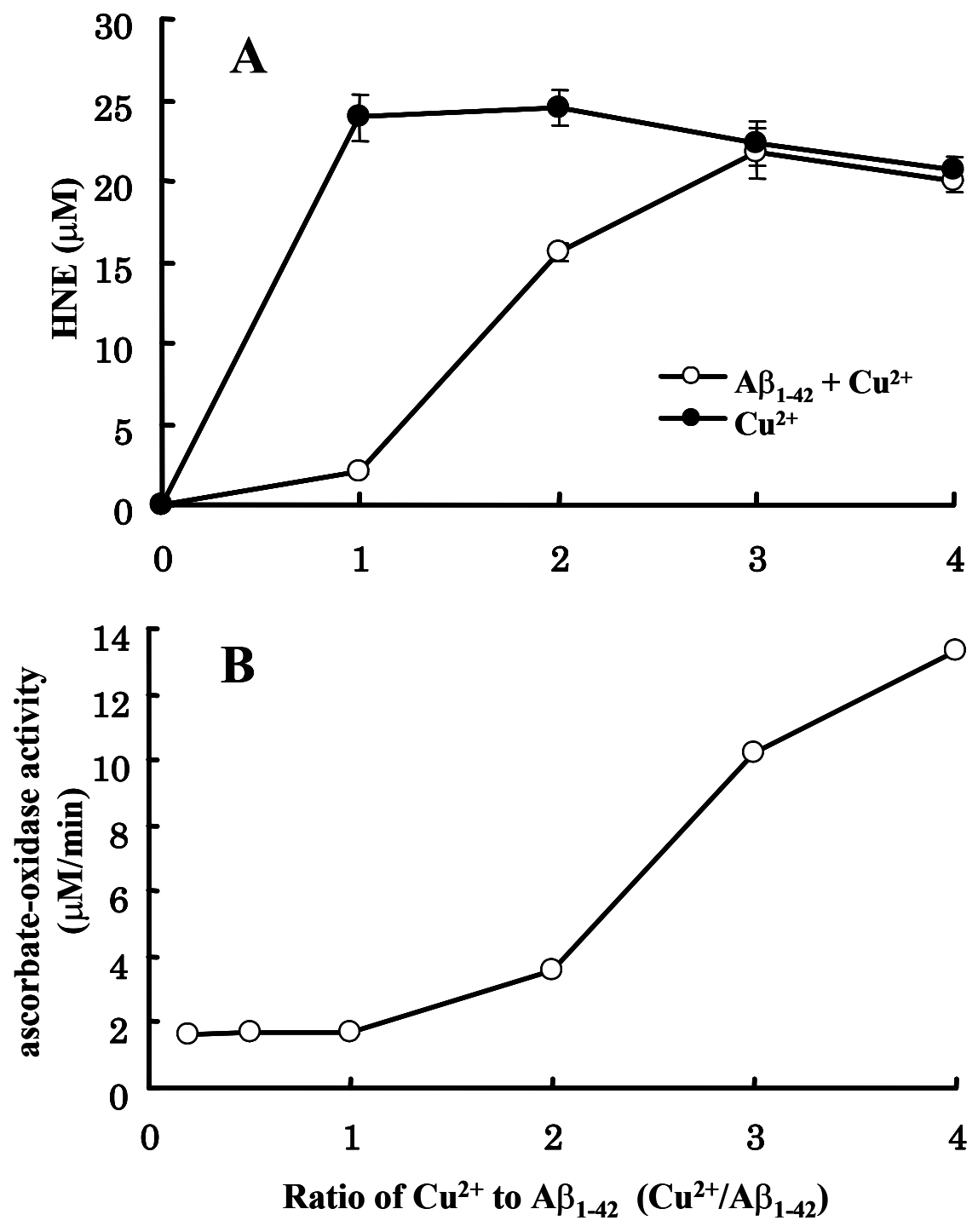
Table 1.

Effects of chelators on phospholipid hydroperoxide and $\mathrm{HNE}$ formations by $\mathrm{A \beta}_{1-42}-\mathrm{Cu}^{2+}$ complex.

a. The reaction mixture containing PLPC $(1 \mathrm{mM})$, ascorbic acid $(2 \mathrm{mM})$ and $\mathrm{A} \beta_{1-42}(10 \mu \mathrm{M})$ $\mathrm{Cu}^{2+}(10 \mu \mathrm{M})(1: 1$ molar ratio) complex was incubated with $10 \mu \mathrm{M}$ chelator for 60 minutes in 5 $\mathrm{mM}$ HEPES buffer $(\mathrm{pH}$ 7.4) at room temperature. An aliquot of the reaction mixture was directly injected into a CL-HPLC to determine phospholipid hydroperoxide.

b. The reaction mixture containing PLPC-OOH $(500 \mu \mathrm{M})$, ascorbic acid $(500 \mu \mathrm{M})$ and $\mathrm{A} \beta_{1-42}$ $(2 \mu \mathrm{M})-\mathrm{Cu}^{2+}(4 \mu \mathrm{M})(1: 2$ molar ratio) complex was incubated with $2 \mu \mathrm{M}$ chelator for 60 minutes in $5 \mathrm{mM}$ HEPES buffer $(\mathrm{pH} 7.4)$ at room temperature. An aliquot of the reaction mixture was directly injected into an HPLC to determine HNE.

Each value represents the mean of three experiments.

\begin{tabular}{|l|c|c|}
\hline Chelators & $\begin{array}{l}\text { Inhibition of phospholipid } \\
\text { hydroperoxide formation (\%) }\end{array}$ & $\begin{array}{l}\text { Inhibition of } \\
\text { HNE formation (\%) }\end{array}$ \\
\hline EDTA & 96 & 93 \\
\hline Oxine & 61 & 64 \\
\hline Trientine & 92 & 87 \\
\hline Penicillamine & 93 & 56 \\
\hline Carnosine & 52 & 6 \\
\hline Deferoxamine & 61 & 82 \\
\hline GHL & 92 & 87 \\
\hline
\end{tabular}

